\title{
GAKUSHUIN NATURAL RADIOCARBON MEASUREMENTS VI
}

\section{KUNIHIKO KIGOSHI}

Faculty of Science, Gakushuin University

Mejiro, Toshimaku, Tokyo, Japan

This list of dates is a continuation of Gakushuin V. Instruments and techniques are essentially the same as those used for Gakushuin III, IV and V.

Age calculations are based on the Libby half life of $\mathrm{C}^{14}, 5570 \pm 30$ $\mathrm{yr}$, and the modern activity given by $0.95 \mathrm{~A}_{\mathrm{ox}}$, i.e., $95 \%$ of the activity of NBS oxalic-acid standard. Errors quoted are the standard deviation obtained from the number of counts only. When observed activities are less than $2 \sigma$ above background, infinite dates are given with a limit corresponding to the activity of $3 \sigma$. When they are greater than $0.95 \mathrm{~A}_{0 \mathrm{x}}-$ $2 \sigma$, modern dates are given with the limit equal to $0.95 \mathrm{~A}_{\mathrm{ox}}-3 \sigma$. Dates for shell samples are computed without correction for environmental and biological isotopic fractionation.

We acknowledge the help of Tamako Morinaga, Hiroko Aizawa, and Hiromi Kobayashi in preparing chemical samples and in routine operation. The descriptions and comments are essentially those of persons submitting the samples.

\section{SAMPLES DESGRIPTIONS}

I. GEOLOGIC SAMPLES

$$
\text { A. Japan }
$$

\section{GaK-809. Sobe, Ryukyu}

Coral from Sobe Quarry, Yomitan-son, Okinawa, Ryukyu Islands $\left(26^{\circ} 23^{\prime} 0^{\prime \prime} \mathrm{N}\right.$ Lat, $127^{\circ} 44^{\prime} 10^{\prime \prime} \mathrm{E}$ Long), lower part of 25-m thick Yomitan Limestone. Coll. and subm. 1964 by Hisao Nakagawa, Tohoku Univ. Comment (H.N.): $70 \mathrm{~m}$ high flat-topped area capped by Yomitan Limestone near Sobe is believed by MacNeil (1960) to be close to original level of fringing reef during Yomitan Time.

GaK-810. Nagake, Ryukyu

$22,450 \pm 650$ 20,500 B.c.

Coral from Nagake Quarry, Minatogawa, Okinawa, Ryukyu Islands (26 $6^{\circ} 35^{\prime \prime} \mathrm{N}$ Lat, $127^{\circ} 45^{\prime} 37^{\prime \prime} \mathrm{E}$ Long), $16 \mathrm{~m}$ below surface of terrace at $+20 \mathrm{~m}$ and formed by Makiminato Limestone. Coll. and subm. 1964 by H. Nakagawa. Comment (H.N.): terrace is thought to be late last interglacial or early last glacial stage (MacNeil, 1960).

\section{Shimabara series, Nagasaki}

Peaty clay from boring at Seno, Fukue-machi, Nagasaki Prefecture (32० $44^{\prime} \mathrm{N}$ Lat, $130^{\circ} 22^{\prime} \mathrm{E}$ Long), alt $45 \mathrm{~m}$, near base of Fukae gravel 
layer. Coll. and subm. 1963 by Hiroyasu Furukawa, Ministry of Agriculture and Forestry.

General Comment (H.F.) : dates fan deposit supposedly contemporary with Ōe layer dated by GaK-319, 19,400 \pm 700 (Gakushuin III).

\section{GaK-513. Shimabara, $-90 \mathrm{~m}$ \\ GaK-514. Shimabara, $-92 \mathrm{~m}$}

$23,200 \pm 800$ 21,250 в.c.

$23,800 \pm 700$ 21,850 в.с.

$1040 \pm 100$

A.D. 910

\section{GaK-730. Arasa, Kagoshima}

Humic soil in volcanic ash, Arasa, Ōshima-machi, Kagoshima Prefecture (31 $30^{\prime} \mathrm{N}$ Lat, $130^{\circ} 39^{\prime} \mathrm{E}$ Long), 0 to $10 \mathrm{~cm}$ below surface. Coll. 1963 by T. Adachi; subm. by Y. Yamada, Nat. Inst. Agricultural Sci. Dates ash fall approximately. Comment (K.K.): dated on total organic carbon in soil.

\section{GaK-816. Shinmatsubara, Fukuoka}

$2690 \pm 160$

Peat from base of Genkai sand dune at Shinmatsubara, Okagakicho,

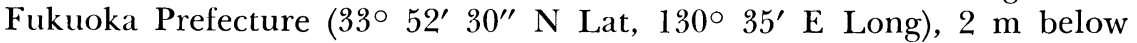
mean sealevel, associated with potsherds of Jomon. Coll. and subm. 1965 by H. Furukawa and Hiromi Mitsushiro, Kōchi Univ. Comment (H.F.): gives maximum age of dune and of shoreline change.

\section{Ōmine series, Kumamoto}

Humic soil from Ōmine, Kosamachi, Kumamoto Prefecture $\left(32^{\circ}\right.$ $40^{\prime} 48^{\prime \prime} \mathrm{N}$ Lat, $130^{\circ} 49^{\prime} 10.4^{\prime \prime} \mathrm{E}$ Long). Taken from layer of recent loam with Paleolithic culture. Coll. and subm. 1965 by H. Furukawa.

General Comment (H.F.): supposed to correlate with Miai Loam at Shimabara dated by GaK-513. (K.K.): dated on total organic carbon.

\section{GaK-817. $\overline{\text { Ōmine, }}-\mathbf{1} \mathrm{m}$}

GaK-818. $\overline{\text { Ōmine, }}-\mathbf{- 1 . 7 5} \mathrm{m}$
$9550 \pm 150$

7600 B.C.

$19,600 \pm 550$

17,650 в.c.

$15,350 \pm 320$

13,400 в.c.

\section{GaK-494. Kashiwabara, Kumamoto}

Peat from Kashiwabara, Shiranui-machi Kumamoto Prefecture $\left(32^{\circ}\right.$ $39^{\prime} 9.6^{\prime \prime} \mathrm{N}$ Lat, $130^{\circ} 40^{\prime} 2.5^{\prime \prime} \mathrm{E}$ Long), mucky peat in Matsubase clay layer, $1.5 \mathrm{~m}$ below surface. Coll. and subm. 1964 by Tatsuo Shibazaki, Res. Inst. for Nat. Resources. Comment (T.S.): underlain by layer of ash probably the Ōe layer dated by GaK-319 (Gakushuin III).

\section{Somi series, $\overline{\text { Oita }}$}

Humic soil in volcanic ash from Somi, Kujumachi, Naoirigun, Ōita Prefecture (33 3' N Lat, 131 ${ }^{\circ} 16^{\prime}$ E Long). Coll. 1963 and subm. 
by Y. Yamada. Purpose of dating is study of formation of volcanic ash soil. Comment (K.K.): clated on total organic carbon.

\section{GaK-727. Somi, 1}

$9060 \pm 100$

7110 в.C.

122 to $158 \mathrm{~cm}$ below surface of ground.

\section{GaK-728. Somi, 2}

$4300 \pm 270$

87 to $102 \mathrm{~cm}$ below surface of ground.

GaK-729. Somi, 3

20 to $38 \mathrm{~cm}$ below surface of ground.

\section{0 в.C.}

$3500 \pm 100$

1550 в.C.

\section{Lake Nojiri series}

Wood from sediments of Lake Nojiri, Nagano Prefecture. Coll. and subm. 1965 by Yutaka Saito, Sinshu Univ.

General Comment: for previous datings see GaK-267, 268 and 269 (Gakushuin III) and N-134, 135, and 136 (Riken II).

\section{GaK-811. Tategahana}

$23,200 \pm 800$

21,250 в.c.

Wood from Tategahana ( $36^{\circ} 49^{\prime} 44^{\prime \prime} \mathrm{N}$ Lat, $138^{\circ} 12^{\prime} 35^{\prime \prime}$ E Long), imbedded in green clay, $40 \mathrm{~cm}$ below surface. Comment (Y.S.): dates latest occurrence of Elephas naumanni at this site.

\section{GaK-812. Sugikubo, 1}

$17,700 \pm 500$

Wood from Sugikubo ( $36^{\circ} 50^{\prime} 2^{\prime \prime}$ N Lat, $138^{\circ} 12^{\prime} 47^{\prime \prime}$ E Long), imbedded in peaty layer, $40 \mathrm{~cm}$ below surface. Comment (Y.S.): dates Sugikubo non-ceramic culture.

\section{GaK-813. Sugikubo, 2}

Wood from same site as GaK-812, $15 \mathrm{~cm}$ below surface.

\section{GaK-786. Akasaka, Gifu}

$$
5200 \pm 110
$$

Humic soil from Akasaka, Gifu Prefecture $\left(35^{\circ} 22^{\prime}\right.$ N Lat, $136^{\circ} 35^{\prime}$ E Long), 5 to $20 \mathrm{~cm}$ below surface. Coll. 1963 and subm. by Y. Yamada. Purpose of dating is study of formation of Terra Rossa-like soil. Comment (K.K.): dated on total organic carbon.

\section{GaK-721. Yakedake, Toyama}

Wood from Nakaborizawa, Yakedake Volcano, Toyama Prefecture (36 $14^{\circ} \mathrm{N}$ Lat, $137^{\circ} 36^{\prime} \mathrm{E}$ Long), imbedded in mudflow deposit between pyroclastics, $10 \mathrm{~m}$ below surface of ground. Coll. and subm. 1964 by Shinpei Kawachi, Hokkaido Univ. 
GaK-687. Hiratsuka

$$
1950 \pm 90
$$

A.D. 0

Driftwood from Hiratsuka Station, Kanagawa Prefecture $\left(\begin{array}{ll}35^{\circ} & 19^{\prime}\end{array}\right.$ 23.5" $\mathrm{N}$ Lat, $139^{\circ} 20^{\prime} 6.5^{\prime \prime} \mathrm{E}$ Long), alt $7.1 \mathrm{~m}$, imbedded in third sand dune, $1 \mathrm{~km}$ from present shoreline, $4 \mathrm{~m}$ below surface. Coll. and subm. 1965 by Yoko Ota, Yokohama Natl. Univ. Comment (Y.O.): dates building of sand dune.

\section{GaK-731. Kokubunji, Tokyo}

$$
2620 \pm 100
$$

Humic soil in volcanic ash from Kokubunji, Tokyo $\left(35^{\circ} 42^{\prime} \mathrm{N}\right.$ Lat, $139^{\circ} 30^{\prime} \mathrm{E}$ Long), 5 to $15 \mathrm{~cm}$ below surface of ground. Coll. 1960 and subm. by Y. Yamada. Comment (K.K.): dated on total organic carbon.

\section{GaK-726. Imaichi, Tochigi}

$\mathbf{3 9 5 0} \pm \mathbf{9 0}$

Humic soil in volcanic ash from Dozawa, Imaichishi, Tochigi Prefecture ( $36^{\circ} 41^{\prime} \mathrm{N}$ Lat, $139^{\circ} 44^{\prime} \mathrm{E}$ Long), 12 to $28 \mathrm{~cm}$ below surface, underlain by Hichihonzakura pumice. Coll. 1963 and subm. by Y. Yamada. Comment (Y.Y.): dates pumice approx. (K.K.) dated on total organic carbon.

\section{GaK-725. Kouncho, Maebashi}

$24,000 \pm 650$

Wood from Kouncho, Maebashi, Gunma Prefecture $\left(36^{\circ} 23^{\prime}\right.$ N Lat, $139^{\circ} 3^{\prime} 30^{\prime \prime} \mathrm{E}$ Long), imbedded in volcanic-mudflow sediment, $11 \mathrm{~m}$ below surface. Coll. and subm. 1965 by Fusao Arai, Gunma Univ.

\section{GaK-495. Katahira, Fukushima}

$29,100 \pm 2000$ 27,150 в.c.

Wood from riverbank of Ōsegawa, Katahira, Fukushima Prefecture

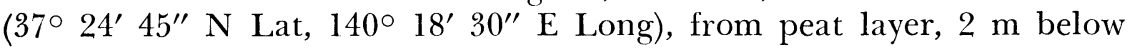
surface, containing Larix kaempferi, Picia glehnii, and Picea konyamai. Coll. and subm. 1964 by Noriko Tomiyama and Kenji Suzuki, Fukushima Univ. Comment: date indicates that layer correlates with Otsuki alluvial fan. See Fukushima series (Gakushuin II).

\section{GaK-515. Mizunuma, Fukushima}

$5610 \pm 110$

Wood from riverbank, Mizunuma, Kanayama-cho, Fukushima Prefecture (37०28' $20^{\prime \prime} \mathrm{N}$ Lat, $139^{\circ} 33^{\prime} 40^{\prime \prime} \mathrm{E}$ Long). In alluvium beneath pumice from Numasawa Volcano. Coll. and subm. 1964 by K. Suzuki.

\section{GaK-450. Nozawa, Fukushima}

$4950 \pm 130$

Wood from Nozawa, Nishiaizu-machi, Fukushima Prefecture $\left(37^{\circ}\right.$ $35^{\prime} \mathrm{N}$ Lat, $139^{\circ} 40^{\prime} \mathrm{E}$ Long), $2.2 \mathrm{~m}$ below surface, at top of pumice layer. Coll. 1963 by S. Nishimura and subm. by K. Suzuki. Comment (K.S.): age expected from topography and deposit was $>10,000$ B.P. 
Wood (Quercus serrata) from Morino, Nishiaizu-machi, Fukushima

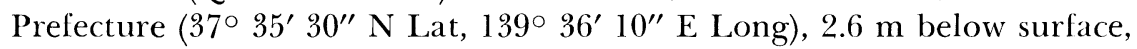
beneath pumice dated by GaK-450. Coll. and subm. 1964 by K. Suzuki. Comment (K.S.): confirms previous dating GaK-450 on same pumice.

\section{GaK-724. Akai-Yachi, Fukushima}

$6500 \pm 110$

4550 в.c.

Peat from base of 3-m peat layer at Akai-Yachi, Minato-machi, Wakamatsu, Fukushima Prefecture $\left(37^{\circ} 30^{\prime} 30^{\prime \prime} \mathrm{N}\right.$ Lat, $140^{\circ} 0^{\prime} 30^{\prime \prime} \mathrm{E}$ Long). Coll. and subm. 1964 by K. Suzuki.

\section{GaK-517. Nihonmatsu, Fukushima}

Wood from Wakamiya, Nihonmatsu, Fukushima Prefecture $\left(37^{\circ}\right.$ $35^{\prime} 10^{\prime \prime} \mathrm{N}$ Lat, $140^{\circ} 25^{\prime} 58.9^{\prime \prime} \mathrm{E}$ Long), in peaty clay containing pumice A. from Adatara Volcano, $4.4 \mathrm{~m}$ below surface. Coll. and subm. 1964 by Tadashi Yoshida, Adatara High School. Comment (T.Y.): underlying peaty clay contains Picea glehnii, Larix kaempheri, Tsuga diversifolia and Pinus koraiensis.

\section{Hayakita series, Hokkaido}

Tarumae volcanic ash soil at Hayakita, Yufutsugun, Hokkaido (42\% $46^{\prime} \mathrm{N}$ Lat, $141^{\circ} 50^{\prime} \mathrm{E}$ Long). Coll. 1963 and subm. by Y. Yamada. General Comment (Y.Y.): dates approximate age of ash fall. For previous estimates see S. Yamada (1958). (K.K.): dated on total organic carbon in soil.

\section{GaK-732. Hayakita, 1}

Modern $<200$

From upper part of Tarumae volcanic ash, Layer a, 0 to $8 \mathrm{~cm}$ below surface. Comment (Y.Y.): date indicates that ash fell during the eruption of Volcano Tarumae in A.D. 1739.

GaK-733. Hayakita, 2

From Layer 1c, 23 to $53 \mathrm{~cm}$ below surface.

GaK-734. Hayakita, 3

From upper part of Layer 1d, 68 to $83 \mathrm{~cm}$ below surface.

\section{Shikotsu series, Hokkaido}

Wood and peat from Shikotsu tephra, and date sequence of volcanic activities of Volcano Shikotsu, Hokkaido. Coll. and subm. 1965 by $\mathrm{H}$. Satoh, Geol. Survey of Japan, except GaK-519. 
GaK-712. Shimoabira

$$
29,200 \pm 600
$$

27,250 B.c.

Peat from Yufutsugun Hayakita-machi, Shimoabira, Hokkaido (42॰ $44^{\prime} 18^{\prime \prime} \mathrm{N}$ Lat, $141^{\circ} 48^{\prime} 33^{\prime \prime} \mathrm{E}$ Long), underlain by terrace deposit and overlain by Shikotsu pumice, top layer of which is correlated with layer at Bibi. Comment (H.S. \& K.K.): dates early phase of activity of Volcano Shikotsu, but date older than GaK-713 and 714 was expected. Presumably younger humus has entered the peat, but no separation of humic acid was tried on sample. Needs further study.

GaK-519. Bibi, 1

$$
\begin{aligned}
& 32,200+4700 \\
& \text { 30,250 B.c. }
\end{aligned}
$$

Charcoal from Shikotsu pumice flow deposit 1 at Bibi, Tomakomai City, Hokkaido (42 $46^{\prime} \mathrm{N}$ Lat, $143^{\circ} 0^{\prime} \mathrm{E}$ Long), $5.5 \mathrm{~m}$ below surface. Coll. and subm. 1964 by Makio Yano, Chiyoda Junior High School.

\section{GaK-713. Bibi, 2}

$31,900 \pm 1700$

$$
\text { 29,950 в.c. }
$$

Charcoal from Shikotsu pumice flow deposit at Bibi, Tomakomai City, Hokkaido (42 $45^{\prime} 53^{\prime \prime}$ N Lat, $141^{\circ} 43^{\prime} 0^{\prime \prime} \mathrm{E}$ Long), $10 \mathrm{~m}$ below surface. Comment (H.S.): dates Shikotsu pumice flow underlain by Shikotsu pumice-fall deposit 1 (Katsui and Satoh, 1963).

GaK-714. Bibi, 3

$32,200 \pm 2000$ 30,250 B.C.

Charcoal from same site as GaK-713, $11 \mathrm{~m}$ below surface, imbedded in Shikotsu pumice-fall deposit 1.

\section{Kutcharo series, Hokkaido}

Samples are from Kutcharo pumice-flow deposit around Kutcharo Caldera, Hokkaido. Coll. and subm. 1965 by H. Satoh.

General Comment (H.S.): dates later age of Kutcharo Caldera because ten pyroclastic flows were erupted in $\mathrm{N}$ district, resulting in formation of Kutcharo Caldera. Pumice flow dated by GaK-867 covers Kutcharo Terrace which is considered Riss-Würm interglacial.

$$
\begin{array}{ll} 
& \\
\text { GaK-866. Kutcharo, } 1 & 32,200+3000 \\
& \mathbf{3 0 , 2 5 0} \text { в.C. }
\end{array}
$$

Charcoal from Kutcharo pumice-flow deposit 1 at Onnenai, Abashiri

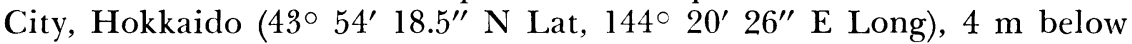
surface. Dates latest pumice flow $\mathrm{N}$ of Kutcharo Caldera.

\section{GaK-867. Kutcharo, 2}

$29,400 \pm 1800$ 27,450 в.c.

Charcoal from Kutcharo pumice flow at Zaimokucho, Kushiro City,

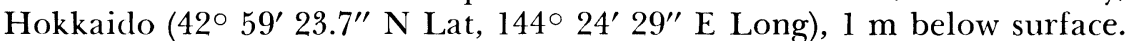
Dates latest pumice flow $\mathrm{S}$ of Kutcharo Caldera. 
GaK-871. Kutcharo, 3

$>33,900$

Charcoal from Koshimizumachi, Sharigun, Hokkaido $\left(43^{\circ} 5 \mathrm{l}^{\prime} 40.5^{\prime \prime}\right.$ N Lat, 144 26' 4.6" E Long), found just below pumice-flow deposit II. Comment (H.S.): Kutcharo pumice-flow deposit II is one of ten layers of pumice flow related to Kutcharo Caldera, and overlain by Kutcharo pumice-flow I dated by GaK-866.

GaK-869. Akan, Hokkaido

Charred wood from Tsuruimura, Akangun, Hokkaido $\left(\begin{array}{ll}43^{\circ} & 14^{\prime} \mathrm{N}\end{array}\right.$ Lat, $143^{\circ} 18^{\prime} 22^{\prime \prime} \mathrm{W}$ Long), imbedded in nonwelded part at base of Akan welded tuff (Ishikawa and Minato, 1955). Coll. and subm. 1965 by H. Satoh.

\section{GaK-870. Teshikagamachi, Hokkaido}

$$
\begin{gathered}
11,720 \pm 220 \\
9770 \text { B.c. }
\end{gathered}
$$

Charred wood from Teshikagamachi, Kawakamigun, Hokkaido $\left(43^{\circ}\right.$ $27^{\prime} 49^{\prime \prime} \mathrm{N}$ Lat, $144^{\circ} 24^{\prime} 42^{\prime \prime} \mathrm{E} \mathrm{Long}$ ), imbedded in volcanic ash, Ma- $\delta$, $3 \mathrm{~m}$ below surface. Coll. 1963 and subm. by H. Satoh. Comment (H.S.): dates formation of somma of Volcanos Mashu and Oakan (Satoh, 1965). For dates on Mashu Caldera see GaK-247 and 248 (Gakushuin II).

\section{Toya series, Hokkaido}

Wood from Datemachi, Abutagun, Hokkaidlo. Samples date Toya pumice which was described by Ishikawa and Minato (1955) and Minato (1965).

\section{GaK-521. Toya, 1}

$13,900 \pm 250$

11,950 в.с.

Wood from (42० $29^{\prime} 24^{\prime \prime} \mathrm{N}$ Lat, $140^{\circ} 49^{\prime} 30^{\prime \prime}$ E Long) Toya pumice flow, $15 \mathrm{~m}$ below surface. Coll. and subm. 1964 by Masao Minato, Hokkaido Univ.

\section{GaK-868. Toya 2}

Wood $\left(42^{\circ} 29^{\prime} 27^{\prime \prime} \mathrm{N}\right.$ Lat, $140^{\circ} 49^{\prime} 54^{\prime \prime} \mathrm{E}$ Long), imbedded in peat directly overlain by Toya pumice flow II. Coll. and subm. 1965 by $\mathrm{H}$. Satoh. Comment (H.S.): dates formation of Toya Caldera.

\section{B. Australia \\ GaK-668. Mount Albert \\ $3520 \pm 100$ \\ 1570 B.C.}

Wood from Mt. Albert, Tasmania (41 $22^{\prime} \mathrm{S}$ Lat, $147^{\circ} 53^{\prime}$ E Long), alt $2600 \mathrm{ft}$. Coll. 1964 from "A" horizon of buried soil, road cut on SW slope of Mt. Albert, by T. N. Caine; subm. by D. Walker, Australian Natl. Univ. Comment (T.N.C.): soil developed on coarse colluvium of Permian sandstone overlain by sandy colluvium. Date is minimum for coarse colluvium, maximum for overlying colluvium and podzolic soil. 


\section{GaK-669. Mathinna Plains Road}

Wood from Mathinna Plains Road, Tasmania $\left(41^{\circ} 25^{\prime} \mathrm{S}\right.$ Lat, $147^{\circ}$ $50^{\prime}$ E Long), alt ca. $1400 \mathrm{ft}$, imbedded in layered colluvial gravel resembling grèzes litées widespread at this altitude and on this lithology in NE Tasmania. Coll. 1964 by T. N. Caine; subm. by D. Walder.

\section{GaK-670. The Talus Valley, Ben Lomond}

$3080 \pm 90$

1130 B.C.

Woody fragments, Talus Valley, Ben Lomond, Tasmania $\left(41^{\circ} 35^{\prime}\right.$ $\mathrm{S}$ Lat, $147^{\circ} 40^{\prime} \mathrm{E}$ Long); in base of peat at $\mathrm{W}$ end of valley. Sampled layer overlies boulders in clay matrix and is covered by ca. 40 in. of peat. Coll. 1965 by T. N. Caine and subm. by D. Walker. Comment (T.N.C.): gives minimum time since matrix material ceased to be removed from large fields of bare boulders.

\section{Pacific}

\section{Lake Inim series, New Guinea}

Organic materials in sediments of valley swamp including Lake Inim, New Guinea ( $5^{\circ} 30^{\prime} \mathrm{S}$ Lat, $143^{\circ} 30^{\prime} \mathrm{E}$ Long), alt ca. $8000 \mathrm{ft}$. Coll. by piston sampler within $2 \mathrm{~m}$ horizontally of pollen-sample site C4. Depths given are beneath water surface. Coll. 1964 and subm. by J. R. Flenley, Australian Natl. Univ.

General Comment (J.R.F.): GaK-829 to 831 date top of a layer of gray clay at $-1690 \mathrm{~cm}$, used as stratigraphic marker. Possibly GaK-830, unexpectedly young, represents younger material that drifted beneath a floating mat including GaK-829, like one at surface today. GaK-662 to 664 date bottom of fully organic deposits at $-1926 \mathrm{~cm}$, and start of pollen diagram with pollen spectra of forest species.

$$
\begin{aligned}
& \text { GaK-829. Lake Inim, }-1680 \text { to }-1685 \mathrm{~cm} \\
& 2240 \pm 90 \\
& \text { GaK-830. Lake Inim, }-1685 \text { to }-1690 \mathrm{~cm} \quad 290 \text { в.c. } \\
& \text { GaK-831. Lake Inim, }-1690 \text { to }-1695 \mathrm{~cm} \quad 2600 \text { B.c. } \\
& \text { GaK-662 Lake Inim, }-1916 \text { to }-1921 \mathrm{~cm} \\
& \text { GaK-663. Lake Inim, }-1921 \text { to }-1926 \mathrm{~cm} \quad 5390 \text { B.c. } \\
& \text { GaK-664. Lake Inim, }-1926 \text { to }-1931 \mathrm{~cm} \quad 6360 \text { B.c. }
\end{aligned}
$$

\section{Lake Birip series, New Guinea}

Organic materials in sediments of Lake Birip, New Guinea $\left(5^{\circ} 30^{\prime}\right.$ $\mathrm{S}$ Lat, $143^{\circ} 30^{\prime} \mathrm{E}$ Long), alt ca. $6000 \mathrm{ft}$. Coll. by piston sampler within 2 
$\mathrm{m}$ horizontally of pollen-sample site A14. Depths are below ground surface. Coll. 1964 and subm. by J. R. Flenley.

General Comment (J.R.F.): GaK-665 to 667 date base of fully organic deposits at $-280 \mathrm{~cm}$ and horizon in pollen diagram typified by spectra rich in grass pollen and fern spores. These dates also are minimum for end of volcanic activity in crater containing the lake. GaK-825 to 828 date yellow silt at $-225 \mathrm{~cm}$, believed to be volcanic ash.

\begin{tabular}{|c|c|c|}
\hline GaK-825. & Lake Birip, -215 to $-220 \mathrm{~cm}$ & $\begin{array}{r}1520 \pm 100 \\
\text { A.D. } 430\end{array}$ \\
\hline GaK-826. & Lake Birip, -220 to $-225 \mathrm{~cm}$ & $\begin{array}{c}1970 \pm 100 \\
20 \text { в.C. } \\
1920 \pm 90\end{array}$ \\
\hline GaK-827. & Lake Birip, -225 to $-230 \mathrm{~cm}$ & A.D. 30 \\
\hline GaK-828. & Lake Birip, -230 to $-235 \mathrm{~cm}$ & $\begin{array}{c}2140 \pm 90 \\
190 \text { в.c. }\end{array}$ \\
\hline GaK-665. & Lake Birip, -270 to $-275 \mathrm{~cm}$ & $\begin{array}{c}2110 \pm 90 \\
160 \text { в.c. }\end{array}$ \\
\hline GaK-666. & Lake Birip, -275 to $-280 \mathrm{~cm}$ & $\begin{array}{c}2440 \pm 90 \\
490 \text { B.c. } \\
2120 \pm 90\end{array}$ \\
\hline GaK-667. & Lake Birip, -280 to $-285 \mathrm{~cm}$ & 170 в.с. \\
\hline
\end{tabular}

II. ARCHAEOLOGIC SAMPLES

\section{A. North America}

\section{Marion County, 13MA30 series}

Samples are from Site 13MA30, in Marion County, Iowa, ca. 1.5 mi W of Dunreath (41 $27^{\prime} \mathrm{N}$ Lat, 93 $11^{\prime} \mathrm{W}$ Long). Coll. 1964 and subm. by D. Gradwohl, Iowa State Univ.

General Comment (D.G.): associated with cultural materials classed as Oneota, which is discussed by Wedel (1959), Henning (1961), and McKusick (1964). GaK-697 may represent dating on a modern rather than aboriginal feature. GaK-698 and GaK-699 are considerably earlier than dates associated with other Oneota sites in Iowa. Typologically, the 13MA30 materials may be earlier than published Oneota materials from Iowa.

GaK-697. Marion County, 13MA30, 1

Wood from post and post hole. Feature 11, A.

GaK-698. Marion County, 13MA30, 2

Charcoal from subterranean storage pit. Feature 5, A.

GaK-699. Marion County, 13MA30, 3

Charcoal from subterranean storage pit. Feature 23, A.
Modern $<\mathbf{2 0 0}$

$$
990 \pm 80
$$$$
\text { A.D. } 960
$$

$1260 \pm 90$

A.D. 690 


\section{Marion County, 13MA41 series}

Samples are from Site 13MA41, in Marion County, Iowa, ca. $1 \mathrm{mi}$ $\mathrm{N}$ of Dunreath $\left(41^{\circ} 28^{\prime} \mathrm{N}\right.$ Lat, $93^{\circ} 10^{\prime} \mathrm{W}$ Long). Coll. 1964 and subm. by D. Gradwohl.

General Comment (D.G.): associated with Woodland cultural materials including pottery with cord-marked and incised decoration, projectile points with contracting base stems. GaK-670 and GaK-671 appear reasonable in terms of similar materials from Nebraska (Kivett, 1952), Illinois (Deuel, 1952) and Iowa (McKusick, 1964).

GaK-670. Marion County, 13MA41, 1

Charcoal from bottom of roasting pit, Feature 1.

GaK-671. Marion County, 13MA41, 2

Charcoal from bottom of roasting pit, Feature 2.

GaK-702. Platte County, 23PL2, Missouri

\section{$1380 \pm 100$} A.D. $\mathbf{5 7 0}$

$$
1650 \pm 80
$$$$
\text { A.D. } 300
$$

$$
2020 \pm 100
$$

70 B.C.

Charcoal from Deister site, 23PL2, Platte County, Missouri (39॰ $12^{\prime}$ $30^{\prime \prime} \mathrm{N}$ Lat, 940 $36^{\prime} 1^{\prime \prime} \mathrm{W}$ Long). Taken from undisturbed roasting hearth of large Indian village, $16 \mathrm{in}$. below present surface. Coll. 1964 by J. M. Shippee and G. Larson; subm. by J. M. Shippee, Kansas City Archaeol. Soc. Comment (J.M.S.): culture is most likely Woodland.

\section{GaK-1005. Cooper County, 23CP40, Missouri}

$$
3620 \pm 90
$$

Charcoal from Collins rock shelter, 23CP40, Cooper County, Missouri (38 $44^{\prime} \mathrm{N}$ Lat, $93^{\circ} 0^{\prime} \mathrm{W}$ Long), 72 to 78 in. deep in the general fill near floor of shelter, but not in association with a diagnostic artifact. Coll. 1958 by F. Collins; subm. by J. M. Shippee. Comment (J. M. S.): cf. GaK-504 (Gakushuin V).

\section{GaK-774. Chase County, 14CS301, Kansas}

$$
2850 \pm 120
$$

900 B.c.

Charcoal from Site 14CS301, in Chase County, Kansas (38 $11^{\prime} 13^{\prime \prime}$ N Lat, $96^{\circ} 22^{\prime} 40^{\prime \prime} \mathrm{W}$ Long), shallow basin containing four cache pits and a large rock complex. Taken from fill of large cache pit, Feature 46. Coll. 1965 by F. A. Calabrese and J. Campbell; subm. by T. A. Witty, Kansas State Hist. Soc. Comment (T.A.W.): may date Archaic material from the site.

\section{GaK-775. Greenwood County, 14GR307, Kansas}

$$
3250 \pm 140
$$

1300 B.C.

Wood charcoal from Site 14GR307, in Greenwood County, Kansas (38 $4^{\prime} 45^{\prime \prime} \mathrm{N}$ Lat, $96^{\circ} 2^{\prime} 0^{\prime \prime} \mathrm{W}$ Long). Site consists of two burned-rock filled hearths probably belonging to Archaic period. Sample was taken from charcoal fill of Hearth 2, Feature 22. Coll. 1965 by F. A. Calabrese and R. Curry; subm. by T. A. Witty. 


\section{Fukui cave series}

$$
\text { B. Japan }
$$

Samples are from Fukui cave, Yoshii-machi, Kitamatsuuragun, Nagasaki Prefecture (33 $17^{\prime} \mathrm{N}$ Lat, 129 $49^{\prime}$ E Long). Coll. 1964 and subm. by C. Serizawa, Tohoku Univ.

General Comment (C.S.): cave deposits are well stratified from Paleolithic (Layer IV to XV) to Jomon (Layer I) culture and described by Serizawa and Kamaki (1965).

\section{GaK-949. Fukui cave, L-II}

$12,400 \pm 350$

Charcoal from humic soil, Layer II, ca. $30 \mathrm{~cm}$ below surface.

\section{GaK-950. Fukui cave, L-III}

$12,700 \pm 500$

Charred wood from humic soil, Layer III, ca. $50 \mathrm{~cm}$ below surface.

\section{GaK-951. Fukui cave, L-VII}

$13,600 \pm 600$

Wood from sand, Layer VII, ca. $1 \mathrm{~m}$ below surface.

GaK-952. Fukui cave, L-XV face.

Charred wood from sand and gravel, Layer XV, ca. $6 \mathrm{~m}$ below sur-

\section{Sakaizaki shell mound series, Kumamoto}

Charcoal and shells from Sakaizaki shell mound II, at Kubo, Sakaizaki, Arao City, Kumamoto (32० $58^{\prime} \mathrm{N}$ Lat, $130^{\circ} 27^{\prime} \mathrm{E}$ Long), alt $15 \mathrm{~m}$, $1 \mathrm{~km}$ off shore line. Coll. and subm. by T. Shibazaki and K. Mishima. Associated with Kurokawa type potteries.

GaK-722a. Sakaizaki, la

Charcoal from third ash layer, 89 to $90 \mathrm{~cm}$ below surface.

GaK-722b. Sakaizaki, 1 b

$3560 \pm 100$

Shells from same collection as GaK-722a.

1610 в.C.

GaK-723a. Sakaizaki, 2a

$3630 \pm 90$

Charcoal from basal (fifth) ash layer, $150 \mathrm{~cm}$ below surface.

1680 B.C.

GaK-723b. Sakaizaki, 2b

$3520 \pm 100$

Shells from same collection as GaK-723a.

1570 B.C.

\section{Araya series, Niigata}

Charcoal from Araya site, Kawanishi-machi, Kitauonumagun, Niigata Prefecture (37० $5^{\prime} \mathrm{N}$ Lat, $138^{\circ} 21^{\prime}$ E Long). 
General Comment (S.S. \& C.S.): associated with microlithic artifacts which are similar to Toma H-point, Hokkaido and probably slightly younger than Yasumiba dated by GaK-604. Site was described by Serizawa (1959) and Serizawa and Ikawa (1960).

GaK-685. Araya, 1

5440 в.c.

Taken from black lens-like layer supposed to be occupation level, 50 to $70 \mathrm{~cm}$ below surface. Coll. 1958 and subm. by S. Sugihara, Meiji Univ. Comment (S.S.): too recent.

GaK-948. Araya, 2

$13,200 \pm 350$

Taken from sandy loam layer, 70 to $80 \mathrm{~cm}$ below surface. Coll. 1958 and subm. by C. Serizawa, Tohoku Univ.

\section{GaK-947. Nakabayashi, Niigata}

Charcoal from Nakabayashi site, at Nakazatomura, Nakauonumagun, Niigata Prefecture (37०3' N Lat, $138^{\circ} 41^{\prime}$ E Long). Taken from Layer III, ca. $1 \mathrm{~m}$ below surface, associated with tanged points. Coll. 1965 and subm. by C. Serizawa. Comment (C.S.): scattered fine charcoal used for dating seems not directly related with tanged point culture, and gives minimum age for culture. For description of site, see Serizawa (1966).

GaK-768. Tabara, Niijima

$3150 \pm 100$

1200 B.c.

Charcoal from Tabara site, Niijima, Honson, Tokyo (34 $22^{\prime} \mathrm{N}$ Lat, $139^{\circ} 13^{\prime} \mathrm{E}$ Long), imbedded in grayish brown clay bed ca. $3 \mathrm{~m}$ below surface. Associated with Obora A, $\mathrm{A}^{\prime}$ and Ongagawa type potteries. Coll. 1965 and subm. by S. Sugihara. Comment (S.S.): dates transitional period from Jomon to Yayoi. Lower layer contains Kasori B type pottery.

\section{GaK-604. Yasumiba, Numazu}

$14,300 \pm 700$

Charcoal from Yasumiba site, Kanaoka, Numazu City $\left(35^{\circ} 10^{\prime} \mathrm{N}\right.$ Lat, $138^{\circ} 50^{\prime} \mathrm{E}$ Long). Taken from hearth overlain by Tachikawa loam, associated with microlithic implements. Coll. and subm. 1965 by S. Sugihara. Comment (S.S.): cf. Araya series of this date list. For detailed studies on Yasumiba site see Sugihara (1965).

\section{Toro series, Shizuoka}

Wood from Toro site, Shizuoka Prefecture $\left(34^{\circ} 57^{\prime} \mathrm{N}\right.$ Lat, $138^{\circ} 25^{\prime}$ E Long), ca. $1 \mathrm{~m}$ below surface of ground. Coll. 1950 and subm. by $\mathrm{S}$. Sugihara.

General Comment (S.S.): series gives sequence of development of rice field which extended to $\mathrm{S}$ from original $\mathrm{N}$ village site. For previous datings, see N-70 to 73 (Riken I) and N-74-a (Riken II). 
GaK-793. Toro, 1

$1960 \pm 80$

Wood from village site, supposed to be a bolt for tenon.

GaK-794. Toro, 2

$2060 \pm 90$

Wood from village site, supposed to be a kind of tenon.

GaK-795. Toro, 3

$2300 \pm 120$

350 B.c.

Wooden pile from remain of rice field, A point.

GaK-796. Toro, 4

$1720 \pm 90$

Wooden pile from remain of rice, field, $\mathrm{C}$ point.

GaK-797. Toro, 5

Wooden plate from $\mathrm{S}$ remain of rice field, $\mathrm{W}$ edge of Tr. E.

$$
2590 \pm 100
$$

640 в.C.

GaK-798. Toro, 6

$2240 \pm 90$

Wooden pile from $S$ remain of rice field, Tr. A, Sq. 4 .

290 B.C.

\section{GaK-686. Yuhama, Hachijo Island}

$5840 \pm 100$

3850 B.c.

Charcoal from Yuhama, Hachijo Island $\left(33^{\circ} 4^{\prime} \mathrm{N}\right.$ Lat, $139^{\circ} 48^{\prime} \mathrm{E}$ Long), associated with stone implements which indicate different charactors from those of Honshu Island. Coll. 1964 and subm. by S. Sugihara.

\section{Kasori shell mound series}

Samples are from Kasori shell mounds, Chiba City $\left(35^{\circ} 36^{\prime} \mathrm{N}\right.$ Lat, $140^{\circ} 10^{\prime}$ E Long). Site consists of number of shell mounds well-stratified from Middle to Latest Jomon culture. Coll. 1965 and subm. by S. Sugihara.

\section{GaK-767. Kasori, 1}

$3630 \pm 90$

Charcoal from Tr. 2, Sq. 2, Loc. B of Kasori, associated with Kasori $\mathbf{B}_{2}$ type pottery. Comment (S.S.): good agreement with expected age.

\section{GaK-1068. Kasori, 2}

$4790 \pm 80$

Charcoal from dwelling site at Kasori $\mathrm{N}$ shell mound, $\mathrm{Sq}$ 2 of Kasori, base of Layer D, associated with Kasori $\mathrm{E}_{1}$ type pottery. Comment (S.S.): good agreement with expected age.

\section{GaK-720. Anyoji, Sado}

$1150 \pm 90$

Charcoal from deposit of furnace for iron-making at Anyoji, Kanaimachi, Sado Island (38 $3^{\circ} 48^{\prime \prime} \mathrm{N}$ Lat, $138^{\circ} 23^{\prime} 10^{\prime \prime} \mathrm{E}$ Long), $1.17 \mathrm{~m}$ to 
$1.87 \mathrm{~m}$ below surface. Coll. 1964 by Katsunori Kera, Sado Mus.; subm. by Ryozaburo Saito, Kanazawa High School. Comment (R.S.): structure of furnace is not like any known in Honshu.

\section{Australia}

\section{Wilson's Promontory series}

Charcoal and shell from excavations at Wilson's Promontory, Victoria ( $38^{\circ} 57^{\prime} \mathrm{S}$ Lat, $146^{\circ} 15^{\prime} \mathrm{E}$ Long). Coll. and subm. 1965 by P. J. F. Cioutts, Australian Natl. Univ.

General Comment (P.J.F.C.): GaK-681 and GaK-683 date upper and lower limits of occupation in dark brown humic soil which caps a Pleistocene dune sequence. Stone industries recovered from this soil appear to be homogeneous from lowest to highest levels and may be attributed to Bondaian culture, though GaK-683 is below lowest level at which type implements of the culture were found. GaK-680 (shell) and GaK-682 (charcoal) date an early occupational horizon in a younger overlying dune series. Shell and charcoal were taken from same level: GaK-680 would appear to be in error, thus exemplifying problem of dates from shell.

GaK-680. Wilson's Promontory, 1

$$
2840 \pm 90
$$

Shells of Cellana tramoserica from an occupational level, excavation No. 2, Site 9B, Yanakie, Square 2, Spit 1.

\section{GaK-681. Wilson's Promontory, 2}

$3060 \pm 100$ No. 5, Site 9A, Yanakie, Square 1, Spit 9.

GaK-682. Wilson's Promontory, 3

$1260 \pm 90$

Charcoal from same occupation as shells of GaK-680, excavation No. 2, Site 9B, Yanakie, Square 1, Spit 2.

GaK-683. Wilson's Promontory, 4

$6550 \pm 100$

4600 в.c.

Charcoal from occupation underlying GaK-681 and 682, excavation No. 5, Site 9A, Yanakie, Square 2, Spit 20.

\section{Bendemeer rock shelters series, New South Wales}

Charcoal samples from two rock shelter sites at Bendemeer, northern New South Wales (30 5 53' S Lat, $151^{\circ} 2^{\prime}$ E Long). Coll. 1965 and subm. by I. McBryde, Univ. of New England. For previous dating and general description of Site 1 see GaK-569 to 572 (Gakushuin V).

General Comment (I.M.): these two sites yielded assemblages of stone implements rich in backed blades (geometric microliths and Bondi 
points) associated with scrapers, burins, and some edge-ground artifacts. See McBryde (1966) for further discussion.

GaK-704. Bendemeer Site 1, 1 (k) II

A.D. 1510

Charcoal from Site 1, Tr. 1, Zone k, Level II, 3 to 4.5 in. below surface of deposit.

GaK-705. Bendemeer Site 1, I (m) II

A.D. 1610

$340 \pm 90$

Charcoal from Site 1, Tr. 1, Zone m, Level II, 3 to 12 in. below surface of deposit.

$500 \pm 130$

GaK-706. Bendemeer Site 1, 1 (k) IIIA A.D. 1450

Charcoal from Site 1, Tr. 1, Zone k, Level IIIA, 6 to 12 in. below surface of deposit.

GaK-707. Bendemeer Site 1, 1 (k) IIIA

$$
320 \pm 80
$$

Scattered charcoal stratified below GaK-706, 12 to 18 in. beneath surface of deposit. On its stratigraphic position this sample should be less recent than GaK-706, but the two determinations are fairly close.

GaK-708. Bendemeer Site 1, 1 (j) IIIA

A.D. 610

$1340 \pm 90$

Charcoal from Site 1, Tr. 1, Zone j, Level IIIA, from near rock face at back of shelter, 9 to 13 in. below surface of deposit.

\section{GaK-710. Bendemeer Site 2, 1 (a) III}

$1020 \pm 80$

Charcoal from Site 2, Tr. 1, Zone a, Level III, concentrated in NW corner of trench, $10 \mathrm{in}$. below surface of deposit.

\section{GaK-711. Bendemeer Site 2, 1 (b) III}

$950 \pm 90$

Charcoal from Site 2, Tr. 1, Zone b, Level III, 10 to 18 in. below surface of deposit. Comment (I.M.): dates most productive part of site in terms of cultural material, and accords well with GaK-710 from same stratigraphic level.

\section{Graman Site 1 series, New South Wales}

Site is a rock shelter on Girrawheen station, Graman, ca. $40 \mathrm{mi}$ NW of Inverell $\left(29^{\circ} 24^{\prime} \mathrm{S}\right.$ Lat, $150^{\circ} 44^{\prime} \mathrm{E}$ Long). Shelter contains occupation deposit in which two stratigraphic levels (I and II) were distinguished. Level I was rich in animal bone, shell, and stone implements, including a number of backed blades (geometric microliths and Bondi points) and two perforated stone flakes probably used as pendants. GaK- 
806 dates level below, which contained far fewer finds of either stone implements or bone and shell. Coll. and subm. 1965 by I. McBryde.

General Comment (I.M.): assemblage of stone implements from this site, with its high proportion of backed blades, is earliest backed-blade industry yet found in northern New South Wales, and one of earliest so far recovered in Australia.

\section{GaK-805. Graman, Site 1, Level I}

$4640 \pm 100$

Charcoal from Graman Area B, Site 1, Tr. 1, Zone b, Level I, 4 to 5 in. below surface of deposit.

GaK-806. Graman, Site 1, Level II

$5450 \pm 100$

Charcoal from Graman Area B, Site 1, Tr. 1, Zone b, Level II, scattered over $\mathrm{S}$ half of this zone, $18 \mathrm{in}$. below surface.

\section{Curracurrang, Royal National Park series, N.S.W.}

Wood charcoal from occupation layers of coastal rock-shelters at Curracurrang, Royal Natl. Park, New South Wales (34 $8^{\prime} 50^{\prime \prime} \mathrm{S}$ Lat, $151^{\circ} 6^{\prime} 25^{\prime \prime}$ E Long). Coll. and subm. 1965 and 1966 by J. V. S. Megaw, Univ. of Sydney. All samples with one exception (GaK-898) are from main rock-shelter (project code 1CU5/-). For previous datings see GaK393, 394 and 481 to 483 (Gakushuin IV).

General Comment (J.V.S.M.): the following dates complete series for main site which seems to reflect certain features of all three phases of McCarthy's Eastern Regional sequence (McCarthy, 1961).

GaK-688. Curracurrang, 1CU5/4(6)

$2360 \pm 90$ layer associated with poorly preserved young adult human skeleton in Cutting 4, Spit 6, 39 in. below surface. Coll. 1965. Comment (J.V.S.M.): this appears to be oldest estimation for backed-blade Bondaian industry on site (cf. GaK-481, 689, 895, and I-1135, the last being $2150 \pm 180$ B.P.) and first Bondaian date associated with a human burial (Megaw, 1966). The Curracurrang Bondaian dates are however considerably younger than the oldest obtained from inland N.S.W., supporting theory of a spread to the coast by introducers of the backed-blade industry (cf. V-24, 33, A.I.A.S. Newsletter, 1966).

GaK-689. Curracurrang, 1CU5/7(4)

$840 \pm 90$

Charcoal from $\mathrm{W}$ face of Cutting 7 , Spit 4, 12 in. below surface. Coll. 1965. Comment (J.V.S.M.): sample, from top of Bondaian occupation, does seem somewhat young when compared with other dates for this layer though still appreciably older than most recent, 'midden' oc- 
cupation phase on site (GaK-462, Gakushuin IV). Possibility of contamination from campers' fires cannot be overruled.

GaK-894. Curracurrang,

$1430 \pm 90$

$1 C U 5 / 4-7 a / b(11-15)$

A.D. 520

Charcoal from thin layer of crushed shell at depth of ca. 36 in. in baulk between Cuttings 4 and 7. Coll. 1966. Comment (J.V.S.M.): date is for a localized layer of compacted shell midden which stratigraphically appears to antedate looser midden occupation dated by GaK462, 483, and 897. It immediately overlays Bondaian layer and it certainly seems old; mixing with older material due to trampling is possible.

\section{GaK-895. Curracurrang, 1CU5/7S(6)}

$2230 \pm 80$

Charcoal from $S$ face of Cutting 7 , Spit 4,34 in below surface Coll. 1966. Comment (J.V.S.M.): sample coll. from lower part of maximum depth of Bondaian layer.

GaK-896. Curracurrang, 1CU5/16(4)

$2110 \pm 90$

160 B.C.

Charcoal from Cutting 16, Spit 4. Coll. 1966. Comment (J.V.S.M.) : sample coll. from temporary hearth in Bondaian layer.

GaK-897. Curracurrang, 1CU5/7E(2) Modern $<250$

Charcoal from $\mathrm{E}$ face Cutting 7, Spit 2, 16 in. below surface. Coll. 1966. Comment (J.V.S.M.): sample coll. from horizon marked by large abalone shells in loosely packed shell midden, the midden having been built up in a pit dug during antiquity into earlier Bondaian material. Recent date compares with earlier estimations (GaK-462, 483) and contrasts with GaK-689 taken from same absolute level below surface.

GaK-898. Curracurrang, 2CU5/B

$1930 \pm 80$

Charcoal from $\mathrm{N}$ face of main E-W cutting 15 in. from surface in second rock-shelter (project code 2CU5/-) ca. 100 yd S of 1CU5/-. Coll. 1966. Comment (J.V.S.M.): sample dates oldest horizon in a partially disturbed deposit associated with backed-blades, edge-ground implements, and 'fabricators' of Bondaian industry. Compares closely with GaK-688, 895, 896, and I-1135 (Megaw, 1966).

\section{Pacific}

\section{Futura, southern New Hebrides series}

Human bones from Futuna, southern New Hebrides $\left(19^{\circ} 30^{\prime} 50^{\prime \prime}\right.$ S Lat, $170^{\circ} 13^{\prime} 30^{\prime \prime}$ E Long). Coll. 1964 by M. E. Shutler and R. Shutler, Jr.; subm. by R. Shutler, Jr., Bishop Mus. Comment (R.S.): spread of 
dates indicates that rock shelter FuRS12 was used for burial over long period of time. Dates provide direct dates for burials, and by association, for listed artifacts.

GaK-758. FuRS1A, Burial 1

$$
620 \pm 90
$$

Human bone from Site FuRS1A, Room 2, 6 in. below surface.

\section{GaK-759. FuRS12, Burial 1}

$$
760 \pm 80
$$

Human bone from Site FuRS12, Trench 3, 16 in. below surface. Associated with shell beads and pendants.

\section{GaK-760. FuRS12, Burial 2}

$$
1460 \pm 90
$$

Human bone from Site FuRS12, Trench 4, ca. 15 in. below surface. Associated with shell adze, pendants, and drilled pecten shell.

\section{GaK-761. FuRS12, Burial 4}

$1640 \pm 90$

Human bone from Site FuRS12, Trench 4, ca. 15 in. below surface. Associated with conus beads and shell pendant.

\section{GaK-762. FuRS12, Burial 9}

$$
1410 \pm 150
$$

Human bone from Site FuRS12, Trench 5 and 6, 12 in. below surface. Associated with shell pendant.

\section{GaK-763. FuRS12, Burial 14}

$$
510 \pm 90
$$

Human bone from Site FuRS12, Trench 5, 20 in. below surface. Associated with conus ring pendant.

\section{GaK-757. Tanna, southern New Hebrides}

$1650 \pm 100$

Human bone from Tanna, southern New Hebrides (19०32' $30^{\prime \prime} \mathrm{S}$ Lat, $169^{\circ} 15^{\prime} 30^{\prime \prime}$ E Long). From Site TaRS1, Pit 10, 5 to $6 \mathrm{ft}$. below surface. Associated with pecked basalt disk and stone flake. Comment (R.S.): dates human skeleton and above mentioned artifacts.

\section{GaK-684. Kampong Sungai Lang,}

$$
\text { E. Malaya }
$$

\section{Mukim Kelanang}

$$
1850 \pm 90
$$

A.D. 100

Wood from site in mangrove swamp on lot No. 1670 at village Kuala Langat district, Selangor, Malaya (approx. $2^{\circ} 45^{\prime} \mathrm{N} \mathrm{Lat}, 101^{\circ} 30^{\prime}$ E Long), associated with Dongson metal work. Coll. by B. A. V. Peacock, Univ. of Malaya; subm. by J. Golson, Australian Natl. Univ. also dated by Geochron (unpub.), GX-280, $2435 \pm 95$, and Australian Natl. Univ. (in press), ANU-27, $2145 \pm 100$. 


\section{Ganj-i-Dareh series}

\section{F. Iran}

Samples are from early Neolithic mound site Ganj-i-Dareh, Iran (34을 N Lat, $47^{\circ}$ E Long). Coll. 1965 and subm. by P. E. L. Smith, Univ. de Montréal, Canada.

General Comment (P.E.L.S.): the two dates are in stratigraphic agreement and are consistent with several occupations of aceramic (prepottery) Neolithic development in central Zagros Mountains. It is believed that occupations represent several small communities of mudwalled houses, during early phases of food-production (Young and Smith, 1966).

GaK-807. Ganj-i-Dareh, 1

$10,400 \pm 150$

Charcoal mixed with ash and earth from ashy zone at base of mound. Coll. and subm. 1965.

GaK-994. Ganj-i-Dareh, 2

$8910 \pm 170$

Charcoal mixed with ash and earth taken from ashy zone ca. $1 \mathrm{~m}$ higher in mound than GaK-807. Coll. 1965 and subm. 1966.

Date lists:
ANU I
Gakushuin I
Polach, Stipp, Golson, and Lovering, 1967
Gakushuin II
Kigoshi, Tomikura, and Endo, 1962
Gakushuin III
Kigoshi and Endo, 1963
Gakushuin IV
Kigoshi, Lin, and Endo, 1964
Kigoshi and Kobayashi, 1965
Gakushuin V
Kigoshi and Kobayashi, 1966
RIKEN I Yamasaki, Hamada, and Fujiyama, 1964
RIKEN II Yamasaki, Hamada, and Fujiyama, 1966

REFERENCES

A.I.A.S. Newsletter, 1966, Recent Australian radiocarbon dates: Australian Inst. of Aboriginal Studies Newsletter, v. 2, no. 3, p. 20-26.

Deuel, T., 1952, Hopewellian communities in Illinois: Illinois State Mus., Sci. Papers, v. 5 .

Henning, D. R., 1961, Oneota ceramics in Iowa: Jour. Iowa Archaeol. Soc., v. 11, no. 2.

Ishikawa, T. and Minato, M., 1955, Age of the welded tuffs in northern Japan: INQUA IV Congress, Rome-Pise (1953), p. 1-8.

Katsui, T. and Satoh, H., 1963, Explanatory text of the geol. map of Japan: MOKOTO-YAMA, Hokkaido Devel. Agency, p. 1-42.

Kivett, M. F., 1952, Woodland sites in Nebraska: Nebraska State Hist. Soc. Pub. in Anthropol., no. 1.

MacNeil, F. S., 1960, Tertiary and Quaternary Gastropoda of Okinawa: U.S. Survey Prof. Paper, no. 339, p. 1-148.

McBryde, I., 1966, Radiocarbon dates for northern New South Wales: Antiquity, Dec. 1966, in press.

McCarthy, F. D., 1961 Report on Australia and Melanesia: Asian Perspectives, v. 5, no. 2, p. 141-155.

McKusick, M. B., 1964, Men of ancient Iowa: Iowa State Univ. Press.

Megaw, J. V. S., 1966, Report on excavations in the south Sydney district, 1964-1965: Australian Inst. of Aboriginal Studies Newsletter, v. 2, no. 3, p. 4-15. 
Minato, M., 1966, C14 age of the Toya ash flow II: Earth Science, no. 82, p. 42-43.

Polach, H. A., Stipp, J. J., Golson, J., and Lovering, F. J., 1967, ANU radiocarbon date list I: Radiocarbon, v. 9, p. 15-27.

Satoh, H., 1965, Explanatory text of the geol. map of Japan: AKANKO, Geol. Survey of Japan, p. 1-82.

Serizawa, C., 1959, A new microblade industry discovered at the Araya Site and the Araya-Type graver: Quaternary Res., v. 1, no. 5, p. 174-181.

1966, Studies on the tanged points from the Nakabayashi Site, Niigata Prefecture, Japan: Rept. of the Res. Inst. for Japanese Culture, no. 2, p. 1-66.

Serizawa, C. and Ikawa, F., 1960, The oldest archaeol. materials trom Japan: Asian Perspectives, Bull. of the Far-Eastern Prehist. Assoc., v. 2, no. 2, p. 1-40.

Serizawa, C. and Kamaki, Y., 1965, The Rock-Shelter of Fukui, Nagasaki Prefecture: Mem. of Tokyo Archaeol. Soc., v. 3, no. 1, p. 1-14.

Sugihara, S., 1965, Microlithic culture of Yasumiba Site, Shizuoka Prefecture: Mem. of Tokyo Archaeol. Soc., v. 3, no. 2, p. 1-33.

Wedel, M. M., 1956, Oneota Sites on the Upper Iowa River: Missouri Archaeologist, v. 21 .

Yamada, S., 1958, Studies on the history of volcanic eruptions of alluvium epoch in Hokkaido in the basis of depositional features of the phyroclastics: Mon. of Assoc. for Geol. Collaboration, no. 8, p. 22-23.

Young, Jr., T. C. and Smith, P. E. L., 1966, Research in the prehistory of central western Iran: Science, v. 153 , no. 3734 , p. 386-391. 